\title{
The Influence of Knowledge Management Towards Employee Work Productivity With Mediation of Competence at PT. Rahayu Perdana Trans
}

\author{
Ranni Dian Octaviana \\ Universitas Ciputra Surabaya \\ roctaviana@magister.ciputra.ac.id \\ https://doi.org/10.37715/rmbe.v1i2.2428
}

\begin{abstract}
The purpose of this research is to find out the impact of knowledge management towards employee work productivity with mediation of competence at PT. Rahayu Perdana Trans. The method used is quantitative research. The population used in this study were employees of PT. Rahayu Perdana Trans who has the criteria has taken at least a Bachelor's degree (S1) study \& already has work experience outside of PT. Rahayu Perdana Trans at least 2years, amounting to 85 people. The data collection technique in this study was carried out by distributing questionnaires using a Likert scale. Based on the results of data analysis, it can be concluded that all existing indicators are valid and reliable so that they have a significant effect.
\end{abstract}

Keywords—Knowledge Management, Employee Work Productivity, Competence.

\section{Introduction}

PT. Rahayu Perdana Trans is a forwarding company engaged in the overall freight forwarding service. The function of this company itself is as EMKL, shipping, customs services, even door to door delivery between islands in Indonesia (Local), Export, and Import using reefer containers. PT. Rahayu Perdana Trans has prepared technological infrastructure by following the times in the 4.0 era at this time so as to facilitate access to communication between internal and external so that the existing technological infrastructure can be used as a knowledge sharing medium because it can spread knowledge or information. Basically, knowledge management is the concept of managing collective knowledge owned by the organization with the main aim of providing added value for the stakeholders who use it, or in other words Knowledge management is a tool that can be used to improve employee performance in public sector organizations, Chong et al, (2011, as cited in Anggraini, 2013). Therefore, to increase employee productivity, it is very necessary to provide knowledge management to increase the competencies that exist in every existing human resource.

The expected benefit of this research is that business actors can determine the effect of knowledge management on employee work productivity through competency mediation. So that it can solve problems that need to be considered in order to improve the performance of each existing HR. The results of the research conducted can be used as a basis for improving knowledge management and competence on employee productivity by similar companies. The results of this study are also expected to be used as a reference for other institutions if they want to improve knowledge management and competence, as well as find mediating variables and moderator variables.

\section{Literature Review}

\subsection{Previous Research}

Previous research was conducted by Arifin (2016) with the title "Pengaruh Knowledge Management, Kompetensi, Motivasi Terhadap Kinerja Karyawan". The purpose of this study is to analyze the effect of knowledge management on employee performance, analyze the effect of competence on employee performance, and analyze the effect of motivation on employee performance. The results of this study itself show that the knowledge management variable has a significant influence on employee performance, the competence variable has an effect on employee performance, the motivation variable has an influence on employee performance. The analysis shows that the knowledge management variable, competence, motivation on employee performance. 
Furthermore, research from Suhartini (2015) with the title "Pengaruh Kompetensi Terhadap Kinerja Pegawai (Studi Perbandingan Antara Fakultas Ekonomi dan Bisnis Islam dan Fakultas Syariah dan Hukum UINAM)". The purpose of this study was to determine the effect of competence on employee performance at FEBI UINAM and to compare employee competence and performance between FEBI and FSHUINAM. The results of this study indicate that the influence of competence on performance has a significant effect on employees of FEBI UINAM, but there is a difference between competence and performance of employees of FEBI and FSH UINAM.

The research entitled "Pengaruh Knowledge Management Terhadap Kinerja Karyawan di Bank Mayapada Kcu Mega Mas Manado" was conducted by Monsow et al. (2018) which aims to analyze the effect of knowledge management on employee performance at (Bank Mayapada Mega Mas main branch) in Manado City. The results show that knowledge management has a positive and significant impact on employee performance. Implementation of knowledge management has a strong and significant relationship with employee performance.

The research entitled "Pengaruh Knowledge Management Terhadap Kompetensi Manajerial para Pengusaha Industri Kecil di Kabupaten Cirebon" conducted by Aufar et al. (Aufar et al., 2016) said that the managerial competence factor can have a significant effect on knowledge management. Respondents in this study were small industrial entrepreneurs in Cirebon Regency, amounting to 90 entrepreneurs as the research sample.

\subsection{Theoretical basis}

\subsubsection{Knowledge Management}

According to Tiwana (2000) Knowledge Management is the process of managing various knowledge assets owned by the organization both in human resources (tacit) and in documents (explicit) so that knowledge is of value to users in carrying out their activities and also to the organization. Legality. Publicity by media aimed at the public will be legally recognized if the publicity is followed or accessed by the public or the wider community. A good form of publicity is one that is easily understood by readers, because the quality of the content or content greatly affects the success of the communication message being conveyed. Knowledge Management can also be defined as the formalization of and access to experience, knowledge, and expertise that creates new skills that enable excellent performance, as well as stimulates innovation and improvement (Kusuma \& Devie, 2013; Setyawan et al., 2014; Stroeva et al., 2015). In a company there are 3 related elements that must be applied in knowledge management, namely:

1. People means Knowledge Management comes from people.

2. Technology is a standard, consistent, and reliable technology infrastructure that supports enterprise tools.

3. Processes consist of capturing, filtering, validating, transforming, and disseminating knowledge throughout the company equipped with carrying out certain procedures and processes.

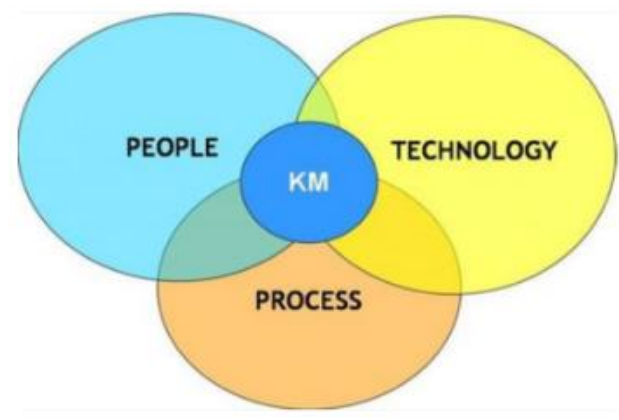

Figure 2.1. Knowledge Management Elements Source: Journal of Tiwana in Sari (2014)

The following are indicators of knowledge management according to Utami dan Ferdiansah (2017), namely:

1. Knowledge acquisition: the process of effectively gathering knowledge and accessing knowledge through internal and external media

2. Knowledge conversion: process the acquired knowledge into knowledge for the entire organization

3. Knowledge application: knowledge that can be used effectively in business

4. Knowledge protection: able to process knowledge well so that it can be counted as an asset

2.2.2. Competence

Competence according to Spencer and Spencer in (Moeheriono, 2012) is a characteristic that underlies a person related to the effectiveness of individual performance in his work or basic characteristics of individuals who 
have a causal relationship or as a cause and effect with criteria that are used as a reference, effective or excellent or superior performance in the workplace. work or in certain situations, while according to Arifin (2016) competence is one of the abilities possessed by every worker to carry out and do work with the skills and knowledge possessed and supported by the work attitude demanded by the job. The following are indicators of competence according to Lyle Spencer and Signe Spencer (1993, as cited in Suhartini, 2015), namely:

1. Achievement and action oriented.

2. Help and serve others.

3. Ability to influence and create impact.

4. Personal effectiveness ability

5. Attitude behavior and behavior patterns

\subsubsection{Productivity}

Productivity is a measuring tool that states how well resources are managed and utilized to achieve optimal results by increasing the ratio continuously and utilizing resources efficiently. The results achieved are the results that were carried out without sacrifices made in earnest (Sedarmayanti, 2001, p. 57). Many factors affect work productivity, one of which is Human Resources (HR). Human resources are an important factor in determining the survival of a company, because employees are one of the production factors that play an important role compared to other production factors. Even if a company has complete facilities and infrastructure, without the support of human resources who are morally good, dynamic, disciplined and united, the company's survival will be slow or even impossible for long (Sutrisno, 2013, p. 14). The following are indicators of productivity according to Sedarmayanti (2001), namely

1. Skills, as measured by:
a. Employee skill level
b. Level of mastery of work
c. Levels using the machine without difficulty

2. Attitude, as measured by:
a. Employee Creativity
b. Employee initiative rate

3. Work results, as measured by:
a. Level of Striving for maximum work
b. Level of Work according to target
c. Level The amount of work in accordance with the provisions
d. Quality level of work results in accordance with the provisions

4. Effectiveness, as measured by:
a. Rate of Avoiding mistakes at work
b. Rate of Completing work on time
c. The level of completing the task well

\section{Research Methods}

\subsection{Analysis Model}

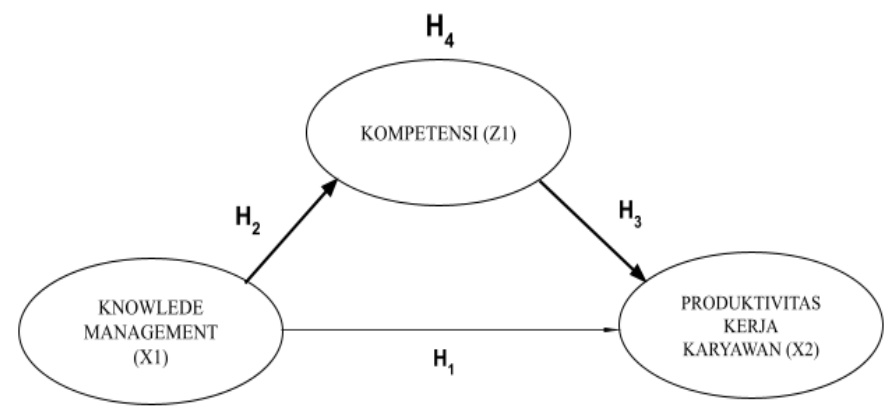

Figure 3.1. Analysis Model

Sources: Data processed, 2021 


\subsection{Research Hypothesis}

Based on the formulation of the problem, research objectives, and theoretical basis above, the hypothesis formed is as follows:

- $\mathrm{H}_{1}$ : There is an effect of Knowledge Management on the work productivity of employees at PT. Trans

- $\mathrm{H}_{2}$ : There is an effect of Knowledge Management on Competence at PT. Trans

- $\mathrm{H}_{3}$ : There is an effect of competence on the work productivity of employees at PT. Trans

- $\mathrm{H}_{4}$ : There is an influence of Competence that mediates Knowledge Management on the work productivity of employees at PT. Trans

\subsection{Research Approach}

The type of research used is quantitative method by processing the data obtained using statistical techniques. The population used in the study were employees of PT. Rahayu Perdana Trans who has the criteria for having studied at least a Bachelor (S1) \& already has work experience outside of PT. Rahayu Perdana Trans at least 2 years, totaling 85 people. The sample used by the researcher to conduct this research is saturated sampling or often called a census because the sample in this study is the entire population taken, the entire number of employees and employees with the criteria of having studied at least Bachelor (S1) \& already have work experience outside of PT. Rahayu Perdana Trans minimum 2 years. Respondents were asked to fill out a questionnaire in which there were several statements and systematic questions. The measurement scale used in this questionnaire is a Likert scale. The Likert scale is a measurement scale used to measure a person's attitudes, opinions, and perceptions about social phenomena (Sugiyono, 2017). In this study, the researchers used a value of 1 to 4 . With the following details:

1. Strongly Disagree (STS)

2. Disagree (TS)

3. Agree (S)

4. Strongly Agree (SS)

In this Independent Variable Knowledge Management as X1 and Competence as X2. And the dependent variable is the employee's work productivity as Y1 because the employee's work productivity is included in the variables that are influenced and become the result of the independent variables.

\subsection{Validity and Reliability}

Validity test is used to measure whether a questionnaire is valid or not according to Gozhali (2005, as cited in Tobing \& Simanjuntak, 2020). The test is carried out by comparing the results of the calculated $r$ value and $r$ table for degree of freedom $(\mathrm{df})=\mathrm{n}-2$, where $\mathrm{n}$ is the number of samples and alpha $=0.05$. The significance test was carried out with criteria using $r$ table at a significance level of 0.05 . If the value is positive and $r$ count $r$ table then the item can be declared valid, and vice versa (Priyatno, 2016). The reliability test is used to determine the consistency of the measuring instrument which usually uses a questionnaire and to obtain a measurement that remains consistent if the measurement is repeated. The method used in this study to measure the scale of the range is Cronbach Alpha. According to Priyatno (2016) reliability $<0.6$ is not good, while 0.7 is acceptable and $>0.8$ is good.

\subsection{Data analysis}

In this study, the data analysis method that will be used is structure equation modeling (SEM). Jogiyanto and Abdillah also explained that SEM can perform factor analysis, path analysis and regression. Path analysis that will be used in this research is partial least square (PLS), using Smart PLS 3.0 software.

\subsubsection{Designing a Structural Model (Inner Model)}

The structural model was evaluated using R-square for the dependent construct and t-test to determine the actual coefficients of the structural path parameters. Stone-Geisser, Q-square test for predictive relevance and t-test and significance of the coefficients of structural path parameters. In assessing the model with PLS, it begins by looking at the R-square for each dependent latent variable. The interpretation is the same as the interpretation in the regression. Changes in the value of R-square can be used to assess the effect of certain independent latent variables on the dependent latent variable whether it has a substantive effect. The results of the R square consist of three, namely: $0.67,0.33,0.19$ for endogenous latent variables in the structural model. 


\subsection{2. $\quad$ Designing a Structural Model (Outer Model)}

According to Ghozali (2014) states that constructs such as "personality" or "attitude are generally seen as factors that give rise to something we observe so that the indicator is reflexive, otherwise if the construct is a clear combination of indicators determined by a combination of variables, the indicator must be formative.

Convergent validity measures the magnitude of the correlation between the construct and the latent variable. In evaluating convergent validity from checking individual item reliability, it can be seen from the standardized loading factor. The standardized loading factor describes the magnitude of the correlation between each measurement item (indicator) and its construct. Correlation can be valid if it has a value > 0.5 Ghozali (2014).

The next evaluation is to see and compare between discriminant validity and square root of average variance extracted (AVE). The measurement model was assessed based on the measurement of cross loading with the construct. If the correlation of a construct with each indicator is greater than the size of the other constructs, then the latent construct predicts the indicator better than the other constructs. The criterion AVE value must be $>0.5$ as a requirement of the reliability of Sholihin and Ratmono (2013, p. 73).

In addition to testing construct validity, a construct reliability test was conducted which was measured by two criteria, namely composite reliability and Cronbach alpha. Composite reliability is a reliability test in PLS which shows the accuracy, consistency of the accuracy of a measuring instrument in carrying out composite reliability and good Cronbach alpha if it has a value of more than 0.7 Sholihin and Ratmono (2013) measurement.

\subsubsection{Path Diagram Construction}

When the design and determination of the outer model and inner model to be tested has been carried out, then the outer model and inner model are translated in the form of a path diagram.

\subsubsection{Estimation: Weight, Path Coefficient, Loading}

The parameter estimation obtained by PLS (Partial Least Square) can be categorized into three:

1. Weight estimate used to create a latent variable score.

2. Reflects the path estimate that connects the latent variables and between latent variables and their indicator blocks (loading).

3. Regarding the means and location of parameters (regression constant values) for indicators and latent variables, Ghozali (2014).

\subsubsection{Evaluasi Goodness of Fit}

The reflexive indicator measurement model is evaluated with convergent and discriminant validity of the indicators and composite reliability for the indicator block. Meanwhile, the outer model with formative indicators is evaluated based on the relative weight and looks at the significance of the weight size. The structural model or inner model is evaluated by looking at the percentage of variance described, namely looking at the value of $\mathrm{R}^{2}$ for the dependent latent construct using the stone geisser Q squares test and also looking at the magnitude of the structural path coefficient. The stability of this estimate was evaluated using the t-statistic test obtained through the bootstrapping procedure of Ghozali (2014).

\subsubsection{Resampling Bootstrapping}

To see the significant effect on hypothesis testing using bootstrapping by looking at the parameter coefficients and the significance value of the $t$ statistic. The value of $t$ table of significance $10 \%=1.65$, therefore the value of the resulting $t$ statistic must be greater than 1.65 Ghozali (2014).

\subsection{Intermediation Evaluation}

Sobel test is used to test whether the effect of the mediating variable shown in the path analysis test results is significant or not. The Sobel test requires the assumption of a large sample size and the mediation coefficient value is normally distributed (Ghozali, 2016, p. 255). The Sobel test in this study was applied by testing the strength of the indirect influence on the social media promotion variable $(\mathrm{X})$ on the purchasing decision variable $(\mathrm{Y})$ through the brand awareness variable $(Z)$. The indirect effect of $X$ to $Y$ through $Z$ is calculated by multiplying path $X \rightarrow Z$ (a) by path $Z \rightarrow Y$ (b) or ab. So the coefficient $a b=\left(c-c^{\prime}\right)$, where $c$ is the effect of $X$ on $Y$ without controlling for $\mathrm{Z}$, while $\mathrm{c}^{\prime}$ is the coefficient of the effect of $\mathrm{X}$ on $\mathrm{Y}$ after controlling for $\mathrm{Z}$. Standard error coefficients $\mathrm{a}$ and $\mathrm{b}$ are written with $\mathrm{Sa}$ and $\mathrm{Sb}$, where the standard error is The indirect effect error SAT is calculated by the following formula: 


$$
S a b=\sqrt{b^{2} S a^{2}+a^{2} S b^{2}+S a^{2} S b^{2}}
$$

To test the significance of the indirect effect, we need to calculate the $t$ value of the ab coefficient using the formula:

$$
t=\frac{a b}{S a b}
$$

The calculated $t$ value is compared with the $t$ table value, which is $>1.96$ for a significant $5 \%$. If the $t$-count value is greater than the t-table value, it can be concluded that there is a mediation effect (Ghozali, 2016).

\section{Result and Discussion}

\subsection{Research Approach}

Respondents in this study were employees of PT. Rahayu Perdana Trans who has the criteria for having studied at least a Bachelor (S1) \& already has work experience outside of PT. Rahayu Perdana Trans at least 2 years, totaling 85 people. The majority of respondents from this research survey were female with a total number of respondents as many as 49 people with a percentage of $57.65 \%$ while male respondents only got a total number of respondents as many as 36 people with a presentation of $42.35 \%$. The education of the majority of respondents from this research survey are employees who have successfully pursued a bachelor's degree with more than 68 respondents with a percentage of $80.00 \%$, while only 17 employees who have received a master's degree with a percentage of $20.00 \%$. the majority of employees who already have work experience 2 years before at PT. Rahayu Perdana Trans amounted to 50 people with a percentage of $58.82 \%$ while the other 35 people with a presentation of $41.18 \%$ had work experience $>2$ years.

\subsection{Descriptive Analysis of Research Variables}

In managing the mean analysis, it can be seen the extent to which the respondents' views respond to the variables studied, namely knowledge management, employee work productivity and competence. Values are divided into 5 categories to measure the mean (average) value for each indicator variable. The five categories are as follows:

\begin{tabular}{|c|c|}
\hline Category & $\begin{array}{c}\text { Range } \\
\text { Mean Value }\end{array}$ \\
\hline Very bad & $1.00-1.79$ \\
\hline Bad & $1.80-2.59$ \\
\hline Enough & $2.60-3.39$ \\
\hline Good & $3.40-4.19$ \\
\hline Very good & $4.20-5.00$ \\
\hline
\end{tabular}

Table 4.1. Mean (Average) Category Division

\subsubsection{Knowledge Management}

Table 4.2. Knowledge Management Variable Descriptive

\begin{tabular}{|l|l|r|r|}
\hline \multicolumn{1}{|c|}{ Variable } & \multicolumn{1}{|c|}{ Indicator } & Mean & Std. Deviation \\
\hline $\begin{array}{l}\text { Knowledge } \\
\text { Management (X1) }\end{array}$ & $\begin{array}{l}\text { I gain knowledge effectively through my own learning } \\
\text { process ( internal) and the learning process from others } \\
\text { (external ) - X1.1 }\end{array}$ & 2,588 & 1.109 \\
\cline { 2 - 4 } & $\begin{array}{l}\text { I am able to manage my knowledge to be a contribution } \\
\text { to the organization - X1.2 }\end{array}$ & 2,659 & 1.08 \\
\cline { 2 - 4 } & $\begin{array}{l}\text { I am able to manage my knowledge to be an effective } \\
\text { resource in business - X1.3 }\end{array}$ & 2,812 & 1.068 \\
\cline { 2 - 4 } & $\begin{array}{l}\text { I am able to manage my knowledge well so that it can be } \\
\text { considered as an asset by the organization - X1.4 }\end{array}$ & 2,941 & 1.033 \\
\hline \multicolumn{2}{|l|}{} \\
\hline
\end{tabular}

Source: SmartPLS Output, 2020

If seen from table 4.2, it can be seen that the mean (average) value of the total respondents to the knowledge management variable is 2.75 and is included in the "enough" category, it means that the average answer given by respondents in this study is in the knowledge management variable. is in the positive region or the agree interval. It can also be seen that the highest mean value in the X1.4 indicator is "I am able to manage the knowledge that I have well so that it can be considered as an asset by the organization" with a mean value of 2.941 and the lowest mean 
value is found in the X1.1 indicator, namely "I gain knowledge systematically effectively through the learning process.

\subsubsection{Employee Work Productivity}

Table 4.3. Descriptive of Employee Productivity Variable

\begin{tabular}{|l|l|r|r|}
\hline \multicolumn{1}{|c|}{ Variable } & \multicolumn{1}{|c|}{ Indicator } & \multicolumn{1}{c|}{ Mean } & Std. Deviation \\
\hline \multirow{3}{*}{$\begin{array}{l}\text { Employee Work } \\
\text { Productivity (X2) }\end{array}$} & My skills within the company improved. - X2.1 & 2.6 & 1.054 \\
\cline { 2 - 4 } & My behavior is acceptable within the company - X2.2 & 2,788 & 1,128 \\
\cline { 2 - 4 } & The work I do is getting better. - X2.3 & 2,871 & 0.955 \\
\cline { 2 - 4 } & The work I do has an impact on the company. - X2.4 & 3.047 & 1.016 \\
\cline { 2 - 4 } & My ability to carry out tasks is good and precise - X2.5 & 2,871 & 1.003 \\
\hline \multicolumn{2}{|l}{ Total Mean } & & 2,8354 \\
\hline
\end{tabular}

Source: SmartPLS Output, 2020

If seen from table 4.3, it can be seen that the mean (average) value of the total respondents to the Employee Productivity variable is 2.835 and is included in the "enough" category, it means that the average answer given by respondents in this study is in the Employee Productivity variable. is in the positive region or the agree interval. It can also be seen that the highest mean value on the X4.4 indicator is "The work I do has a very positive impact on the company." With a mean value of 3.047 and the lowest mean value is found in the X2.1 indicator, namely "My skills in the company have increased" with a value of 2.6.

\subsubsection{Competence}

Table 4.4. Descriptive Competency Variable

\begin{tabular}{|c|c|c|c|}
\hline Variable & Indicator & Mean & Std.Deviation \\
\hline \multirow[t]{5}{*}{ Ompetence (Z) } & I have clear work goals within the company. Z1.1 & 2,835 & 1,146 \\
\hline & $\begin{array}{l}\text { I can place myself in the company and have a character or } \\
\text { disposition that can match the position I am assigned - Z1.2 }\end{array}$ & 2,729 & 0.999 \\
\hline & I have a good ability to accept new knowledge. - Z1.3 & 2,906 & 1.047 \\
\hline & I have the skills the company needs. - Z1.4 & 2,976 & 1.084 \\
\hline & $\begin{array}{l}\text { I Behavior attitude and pattern of good behavior for the } \\
\text { company - Z1.5 }\end{array}$ & 2,871 & 1.082 \\
\hline \multicolumn{2}{|l|}{ Total Mean } & & 2,8634 \\
\hline
\end{tabular}

Source: SmartPLS Output, 2020

If seen from table 4.4. it can be seen that the mean (average) value of the total respondents to the competency variable is 2.8634 and is included in the "enough" category, it means that the average answer given by respondents in this study in the competency variable is in the positive area or the agree interval. . It can also be seen that the highest mean value on the Z1.4 indicator is "I have the skills the company needs." with a mean value of 2.976 and the lowest mean value is found in the Z1.2 indicator, namely "I can place myself in the company and have a character or character that can match the position I carry" with a value of 2.729 .

\subsection{Evaluation of Measurement Model (Outer Model)}

\subsubsection{Validity Test Results}

The indicator is declared to meet convergent if the outer loading value for each indicator in each construct is more than 0.7. The results of the loading value of each indicator with its construct in this study are as follows:

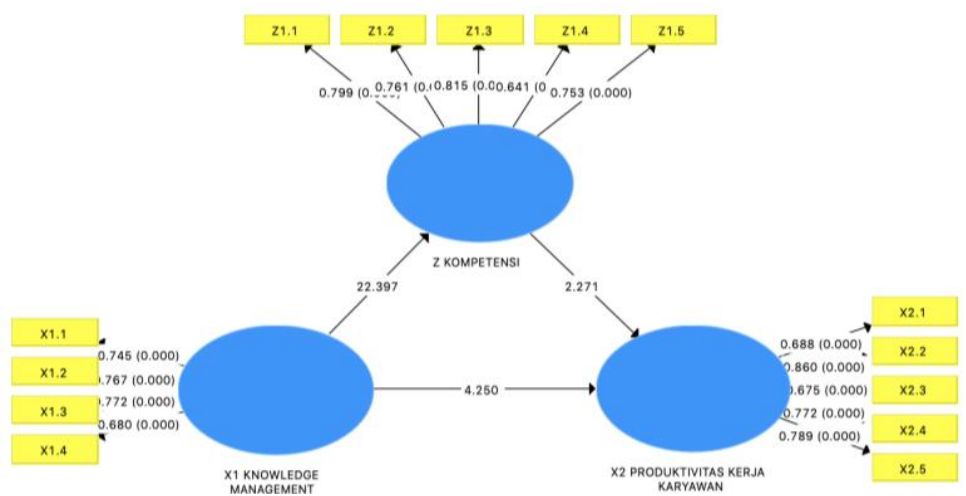

Figure 4.1. Outer Loading

Source: SmartPLS Output, 2020 
Table 4.5. Outer Loading Table

\begin{tabular}{|c|c|c|c|c|}
\hline Variable & Indicator & Loading Factor & Conclusion & AVE . value \\
\hline \multirow{4}{*}{$\begin{array}{l}\text { Knowledge } \\
\text { Management (X1) }\end{array}$} & $\mathrm{X} 1.1$ & 0.745 & Valid & \multirow{4}{*}{$\begin{array}{l}\text { Knowledge } \\
\text { Management (X1) }\end{array}$} \\
\hline & $\mathrm{X} 1.2$ & 0,767 & Valid & \\
\hline & $\mathrm{X} 1.3$ & 0,772 & Valid & \\
\hline & $\mathrm{X} 1.4$ & 0,68 & Valid & \\
\hline \multirow{5}{*}{$\begin{array}{l}\text { Employee Work } \\
\text { Productivity (X2) }\end{array}$} & $\mathrm{X} 2.1$ & 0,799 & Valid & \multirow{5}{*}{$\begin{array}{l}\text { Employee Work } \\
\text { Productivity (X2) }\end{array}$} \\
\hline & $\mathrm{X} 2.2$ & 0,761 & Valid & \\
\hline & $\mathrm{X} 2.3$ & 0,815 & Valid & \\
\hline & $\mathrm{X} 2.4$ & 0,641 & Valid & \\
\hline & $\mathrm{X} 2.5$ & 0,753 & Valid & \\
\hline \multirow[t]{5}{*}{ Competence (Z) } & $\mathrm{Z} 1.1$ & 0,688 & Valid & \multirow[t]{5}{*}{ Competence (Z) } \\
\hline & $\mathrm{Z} 1.2$ & 0,86 & Valid & \\
\hline & $\mathrm{Z} 1.3$ & 0,675 & Valid & \\
\hline & $\mathrm{Z} 1.4$ & 0,772 & Valid & \\
\hline & Z1.5 & 0,789 & Valid & \\
\hline
\end{tabular}

In Table 4.5. shows that there are several variables that are not greater than 0.7 such as $\mathrm{X} 1.4, \mathrm{X} 2.4$ and Z1.3. However, Hair et al. (2017) explained that if the loading factor is still above 0.045, it can still be considered in research. This makes all the variables listed in table 5.8 declared valid.

Table 4.6. Table AVE 1

\begin{tabular}{|c|c|}
\hline Variable & AVE \\
\hline Knowledge Management (X1) & 0.551 \\
\hline Employee Work Productivity (X2) & 0.577 \\
\hline Competence (Z) & 0.572 \\
\hline \multicolumn{2}{|c|}{ Source: SmartPLS Output, 2020 } \\
\hline
\end{tabular}

The AVE value of the criteria must be $>0.5$ as a condition of the reliability of Sholihin and Ratmono (2013). Then table 5.9 shows that all variables used are greater than 0.5 so that all variables can be declared valid.

Table 4.7. Cross Loading Table

\begin{tabular}{|l|r|r|r|}
\hline & $\begin{array}{c}\text { X1 } \\
\text { KNOWLEDGE } \\
\text { MANAGEMENT }\end{array}$ & $\begin{array}{c}\text { X2 } \\
\text { EMPLOYEE WORK } \\
\text { PRODUCTIVITY }\end{array}$ & $\begin{array}{c}\text { Z } \\
\text { COMPETENCE }\end{array}$ \\
\hline $\mathbf{X 1 . 1}$ & 0.745 & 0.634 & 0.696 \\
\hline $\mathbf{X 1 . 2}$ & 0.767 & 0.764 & 0.690 \\
\hline $\mathbf{X 1 . 3}$ & 0.772 & 0.696 & 0.644 \\
\hline $\mathbf{X 1 . 4}$ & 0.680 & 0.596 & 0.539 \\
\hline $\mathbf{X 2 . 1}$ & 0.618 & 0.688 & 0.638 \\
\hline $\mathbf{X 2 . 2}$ & 0.804 & 0.860 & 0.765 \\
\hline $\mathbf{X 2 . 3}$ & 0.634 & 0.675 & 0.540 \\
\hline $\mathbf{X 2 . 4}$ & 0.702 & 0.772 & 0.655 \\
\hline $\mathbf{X 2 . 5}$ & 0.685 & 0.789 & 0.713 \\
\hline $\mathbf{Z 1 . 1}$ & 0.610 & 0.668 & 0.799 \\
\hline $\mathbf{Z 1 . 2}$ & 0.686 & 0.686 & 0.761 \\
\hline $\mathbf{Z 1 . 3}$ & 0.734 & 0.716 & 0.815 \\
\hline $\mathbf{Z 1 . 4}$ & 0.592 & 0.637 & 0.641 \\
\hline $\mathbf{Z 1 . 5}$ & 0.653 & 0.596 & 0.753 \\
\hline
\end{tabular}

Abdillah and Jogiyanto (2015) state that a variable is said to be valid if the cross loading is greater than 0.7. Then table 4.7. shows the cross loading of each indicator is above 0.7 so it can be said to be.

Table 4.8. AVE Root Relationship and Latent Variable Correlation

\begin{tabular}{|l|l|r|r|r|}
\hline & AVE & AVE . root & $\begin{array}{c}\text { Latent Variable } \\
\text { Correlation }\end{array}$ & $\begin{array}{c}\text { AVE Root Relationship and } \\
\text { Latent Variable Correlation }\end{array}$ \\
\hline $\mathbf{X 1}>\mathbf{X 2}$ & 0.551 & 0.742 & 1,000 & $0.742>0.910$ \\
\hline $\mathbf{X} 1>\mathbf{Z}$ & 0.551 & 0.742 & 0.876 & $0.742>0.8764$ \\
\hline $\mathbf{Z}>\mathbf{X 2}$ & 0.572 & 0.756 & 1,000 & $0.756>0.8697$ \\
\hline
\end{tabular}




\subsubsection{Reliability Test}

The method used in this study to measure the scale of the range is Cronbach Alpha. According to Priyatno (2016) reliability $<0.6$ is not good, while 0.7 is acceptable and $>0.8$ is good.

Table 4.9. Cronbach's Alpha

\begin{tabular}{|l|r|}
\hline \multicolumn{1}{|c|}{ Variable } & Cronbach's Alpha \\
\hline Knowledge Management (X1) & 0.728 \\
\hline Employee Work Productivity (X2) & 0.814 \\
\hline Competence (Z) & 0.810 \\
\hline
\end{tabular}

Sumber: Output SmartPLS, 2020

Table 4.9 shows Cronbach's alpha of each variable above 0.7 so that the construct can be said to be reliable..

Table 4.10 Composite Reliability Table

\begin{tabular}{|l|r|}
\hline \multicolumn{1}{|c|}{ Variable } & Composite Reliability \\
\hline Knowledge Management (X1) & 0.830 \\
\hline Employee Work Productivity (X2) & 0.871 \\
\hline Competence (Z) & 0.869 \\
\hline
\end{tabular}

Source: SmartPLS Output, 2020

Table 4.10. shows the Composite Reliability of each variable showing above 0.7 so that the construct can be said to be reliable.

\subsection{Inner Model Analysis}

\subsection{1. $R$ Square $\left(R^{2}\right)$}

The coefficient of determination shows the magnitude of the contribution of the exogenous latent variable to the endogenous latent variable.

Table 4.11. R Square $\left(\mathrm{R}^{2}\right)$

\begin{tabular}{|l|r|}
\hline \multicolumn{1}{|c|}{ Variable } & Composite Reliability \\
\hline Employee Work Productivity (X2) & 0.858 \\
\hline Competence (Z) & 0.756 \\
\hline
\end{tabular}

Source: SmartPLS Output, 2020

Table 4.11. shows that the R-Square of the Employee Productivity variable has a value of 0.858 , which means that the Employee Productivity variable by the knowledge management construct is $85.8 \%$. The R-Square value of the Competence variable has a value of 0.756 , which means that the competency variable can be explained by the knowledge management construct and the employee's work productivity is $60.8 \%$

\subsubsection{Path Coefficient}

Path coefficient test is used to determine the magnitude of the influence between variables in this study.

Table 4.12. Path Coefficient

\begin{tabular}{|l|rr|}
\hline \multicolumn{1}{|c|}{ Variable } & \multicolumn{1}{c|}{ T-Statistics } \\
\hline $\begin{array}{l}\text { Knowledge Management (X1) > } \\
\text { Employee Work Productivity (X2) }\end{array}$ & & 4,250 \\
\hline $\begin{array}{l}\text { Knowledge Management (X1) > } \\
\text { Competence (Z) }\end{array}$ & 22,397 \\
\hline $\begin{array}{l}\text { Competence (Z) > } \\
\text { Employee Work Productivity (X2) }\end{array}$ & 2,271 \\
\hline
\end{tabular}

$$
\text { Source: SmartPLS Output, 2020 }
$$

Table 4.12 shows that the path coefficient value is greatest in the influence of knowledge management on competence with a value of 22,397. Then followed by the influence of knowledge management on employee work productivity with a value of 4,250 and finally the influence of competence on employee productivity with a value of 2,271. Table 4.12. shows that the overall influence between variables in this study has a positive path coefficient.

\subsection{Evaluation of Mediation Variables}

Sobel test was used to test whether the mediating variables generated in the path analysis were significant or not.

Table 4.13. Sobel Test Results

\begin{tabular}{|l|c|c|}
\hline Description & Calculation & Results \\
\hline Sab & $S a b: \sqrt{(0,1204 \times 0,0025+0,7563 \times 0,0025)}$ & 0,0468 \\
\hline Zcount & $T=\frac{0,8697 \times 0,3471}{\sqrt{(0,1204 \times 0,0025+0,7563 \times 0,0025)}}$ & 6,450275 \\
\hline \multicolumn{2}{|c|}{ Source: SmartPLS Output, 2020 } \\
\hline
\end{tabular}




\section{Conclusions and Practical Implication}

\subsection{Conclusion}

There is an influence of knowledge management on employee work productivity. Based on these results, hypothesis 1 is accepted. The increase in knowledge management variables carried out by PT. Rahayu Perdana Trans can increase the work productivity of PT. Rahayu Perdana Trans. There is an influence of knowledge management on competence. Based on these results, hypothesis 2 is accepted. The increase in knowledge management variables carried out by PT. Rahayu Perdana Trans can improve the competence of PT. Rahayu Perdana Trans. There is an influence of competence on employee work productivity. Based on these results, hypothesis 3 is accepted. The increase in competency variables carried out by PT. Rahayu Perdana Trans can increase the work productivity of PT. Rahayu Perdana Trans. There is an influence of knowledge management on employee work productivity through competence. Based on these results, hypothesis 4 is accepted. The increase in knowledge management variables carried out by PT. Rahayu Perdana Trans can increase the work productivity of PT. Rahayu Perdana Trans.

\subsection{Practical Implication}

The results of the analysis conclude that knowledge management affects employee productivity through competence. Therefore, PT. Rahayu Perdana Trans will develop policies used to increase employee productivity at PT. Rahayu Perdana Trans as follows:

Table 5.1. Managerial Implications

\begin{tabular}{|c|c|}
\hline & \\
\hline $\begin{array}{l}\text { The old marketing response } \\
\text { regarding sales price decisions is } \\
\text { because they do not understand } \\
\text { the company's product } \\
\text { knowledge in depth, so it is difficult } \\
\text { to make decisions. } \\
\text { Update schedule from customer } \\
\text { service that is not updated quickly } \\
\text { Because the company's customers } \\
\text { are increasing day by day, but the } \\
\text { availability of the Customer } \\
\text { Service team has not increased so } \\
\text { there are often delays in updating } \\
\text { the schedule for customers. } \\
\text { Ops team that is not so solution } \\
\text { Because the Ops team only does } \\
\text { orders from the marketing/customer } \\
\text { service team, so the Ops team is } \\
\text { afraid if they have to give } \\
\text { suggestions to customers }\end{array}$ & $\begin{array}{l}\text { To keep up with the recent business competition, PT. Rahayu Perdana Trans } \\
\text { should pay more attention to and build knowledge management and } \\
\text { competence in the company. In knowledge management, the things that need } \\
\text { to be considered are: } \\
\text { 1. Build infrastructure with the right technology, such as: } \\
\text { Develop fleet infrastructure to support the company's EMKL activities, } \\
\text { by adding GPS in every existing reefer container. } \\
\text { 2. Build a conceptual infrastructure with a competency backbone } \\
\text { 3. Create a storage area and the things that come with it } \\
\text { 4. Set high standards for quality and usability } \\
\text { What is needed in implementing knowledge management is human } \\
\text { resources and technology. In addition to individuals who play a role in } \\
\text { sharing knowledge, there is also a need for someone who is a regulator of } \\
\text { knowledge management. This is very necessary for the smooth process of } \\
\text { implementing knowledge management, while the role of technology is } \\
\text { only as a tool to help. } \\
\text { If in competence, the things that need to be considered are: } \\
\text { 1. Improve negotiation skills } \\
\text { 2. Active during meetings } \\
\text { 3. Express your opinion briefly and clearly } \\
\text { 4. Sharpen your leadership spirit } \\
\text { 5. Say "no" if you can't } \\
6 \text {. Emotion control }\end{array}$ \\
\hline
\end{tabular}

\section{References}

Abdillah, W., \& Jogiyanto. (2015). Partial Least Square (PLS): alternatif Structural Equation Modeling (SEM) dalam penelitian bisnis. Yogyakarta: Penerbit Andi.

Anggraini, N. D. (2013). Pengaruh praktek knowledge management terhadap kinerja organisasi (Studi empiris pada satuan kerja perangkat daerah Kota Salatiga). Universitas Diponegoro.

Arifin, M. (2016). Pengaruh knowledge management, kompetensi, motivasi terhadap kinerja karyawan. Jurnal Performance: Bisnis Dan Akuntansi, VI(1), 1-13.

Aufar, E., Adman, A., \& Suwatno, S. (2016). Pengaruh knowledge management terhadap kompetensi manajerial para pengusaha Industri kecil di Kabupaten Cirebon. Manajerial: Jurnal Manajemen Dan Sistem Informasi, 15(1), 58-69. https://doi.org/https://doi.org/10.17509/manajerial.v15i1.9472 
Ghozali, I. (2014). Structural equation modeling metode alternatif dengan Partial Least Square (PLS) dilengkapi software SmartPLS 3.00 Xistat 2014 dan WarpPLS 4.0 (4th ed.). Semarang: Badan Penerbit Universitas Diponegoro Semarang.

Ghozali, I. (2016). Aplikasi analisis multivariete dengan program IBM SPSS 23 (8th ed.). Semarang: Badan Penerbit Universitas Diponegoro.

Kusuma, F. S. D., \& Devie. (2013). Analisa pengaruh knowledge management terhadap keunggulan bersaing dan kinerja perusahaan. Business Accounting Review, 1(2), 161-171.

Moeheriono, M. (2012). Pengukuran kinerja berbasis kompetensi. Jakarta: PT Raja Grafindo Persada.

Monsow, E. Y., Runtuwene, R. F., \& Rumawas, W. (2018). Pengaruh knowledge management terhadap kinerja karyawan di Bank Mayapada Kcu Mega Mas Manado. JURNAL ADMINISTRASI BISNIS (JAB), 6(001), 1-10. https://doi.org/https://doi.org/10.35797/jab.6.001.2018.18955.\%25p

Priyatno, D. (2016). Belajar alat analisis data dan cara pengolahannya dengan SPSS. Yogyakarta: Gava Media.

Sarstedt, M., Ringle, C. M., \& Hair, J. F. (2017). Treating unobserved heterogeneity in PLS-SEM: A multi-method approach. In Partial Least Squares Path Modeling (pp. 197-217). Springer International Publishing. https://doi.org/10.1007/978-3-319-64069-3_9

Sedarmayanti. (2001). Sumber daya manusia dan produktifitas kerja. Bandung: CV. Mandar Maju.

Setyawan, A. A., Dharmmesta, B. S., Purwanto, B. ., \& Nugroho, S. S. (2014). Business relationship framework In emerging market: A preliminary study in Indonesia. International Journal of Economics and Business Administration, II(Issue 1), 59-72. https://doi.org/10.35808/ijeba/34

Sholihin, M., \& Ratmono, D. (2013). Analisis SEM-PLS dengan WarpPLS 7.0 untuk hubungan nonlinier dalam penelitian sosial dan bisnis. Yogyakarta: Penerbit Andi.

Stroeva, O., Lyapina, I. R., Konobeeva, E. E., \& Konobeeva, O. E. (2015). Effectiveness of management of innovative activities in regional socio-economic systems. European Research Studies Journal, XVIII(Issue 3), 63-76. https://doi.org/10.35808/ersj/455

Sugiyono, S. (2017). Metode penelitian kuantitatif, kualitatif, dan R\&D. Bandung: Alfabeta.

Suhartini, E. (2015). Pengaruh Kompetensi terhadap kinerja pegawai (Studi perbandingan antara fakultas ekonomi dan bisnis islam dan fakultas syariah dan hukum UINAM). Jurnal Minds: Manajemen Ide Dan Inspirasi, 2(1), 61-78. https://doi.org/https://doi.org/10.24252/minds.v2i1.4633

Sutrisno, E. (2013). Manajemen sumber daya manusia. Kencana Prenada media group.

Tiwana, A. (2000). The knowledge management toolkit: Practical techniques for building a knowledge management system. New Jersey: Prentice hall PTR.

Tobing, A. R. br, \& Simanjuntak, J. (2020). Pengaruh keselamatan dan kesehatan karyawan terhadap kinerja karyawan PT. Citra Shipyard. Journal of Technopreneurship on Economics and Business Review, 2(1), 1-11. https://doi.org/10.37195/jtebr.v2i1.47

Utami, C. W., \& Ferdiansah, M. (2017). Development of knowledge management model in establishing innovation and company performance in UMKM/SME in Indonesia. European Research Studies Journal, XX(4B), 655665. 